Wayside Shrines: Everyday Religion in Urban India

\title{
From the Heavens to the Streets: Pune's Wayside Shrines
}

\section{Borayin Larios}

\section{(2) OpenEdition \\ 1 Journals}

Electronic version

URL: http://journals.openedition.org/samaj/4549

DOI: $10.4000 /$ samaj.4549

ISSN: $1960-6060$

Publisher

Association pour la recherche sur l'Asie du Sud (ARAS)

\section{Electronic reference}

Borayin Larios, «From the Heavens to the Streets: Pune's Wayside Shrines », South Asia

Multidisciplinary Academic Journal [Online], 18 | 2018, Online since 22 May 2018, connection on 10

December 2020. URL : http://journals.openedition.org/samaj/4549; DOI : https://doi.org/10.4000/ samaj.4549

This text was automatically generated on 10 December 2020.

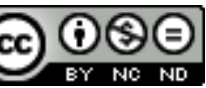

This work is licensed under a Creative Commons Attribution-NonCommercial-NoDerivatives 4.0 International License. 


\title{
From the Heavens to the Streets: Pune's Wayside Shrines
}

\author{
Borayin Larios
}

In 2014 The (in)famous Bollywood hit PK created an uproar among Hindu nationalists and right-wing groups who called for a boycott of the film, which ultimately lead to the physical vandalization of cinema halls, the tearing of posters, and the use of traditional media as well as social media to abuse the director, filmmakers, and the actors for the film's portrayal of their religion (Qadri and Mufti 2016). ${ }^{1}$ The plot of the movie is that Peekay, who is an alien that lands in India, is unable to return to his planet after his "remote control" is stolen. As he tries to find his way back home, he learns from humans that only "God" will be able to help him find the device. As he searches for "God", he is confronted by the paradoxical elements of India's different religious dogmas and practices. Jaggu is the female lead of the movie. She is a television news reporter and a non-traditional and progressive Hindu girl who falls in love with a Muslim man from Pakistan while traveling in Europe and the couple decides to marry. Jaggu's father, however, is a very devout follower of a Hindu godman (Tapasvi) who opposes his daughter's union with a Muslim man. After the flop of their attempt to marry, because of religious differences, Jaggu meets Peekay back in India as he is distributing leaflets about a missing "God". She is fascinated by Peekay's quest and convinces the TV channel head to make a show with Peekay exposing the truth about different religions. About midway through the movie (1.41.19 min.-1.43.31 min.) $)^{2}$ there is a scene that depicts the installation of a wayside shrine by Peekay, the hero of the film, outside of the Department of Mathematical Sciences of Delhi University. In this part of the movie, Peekay brings the devout father of Jaggu along with a TV crew to the entrance of the university in order for Peekay to prove to Jaggu's father that religion is nothing but a money-making "business driven by fear" (Hindi: dar kā biznes). He explains to Jaggu's father that because exams are currently being conducted at the college students are terrified. Peekay then approaches one of the trees at the gates of the university and takes a large rock and places it in the flower bed in front of it. He calls the stone the "factory's machine" and the coins and bills he puts in front of the stone are the "investment." He then takes out a pān ${ }^{3}$ packet and smears the stone with it leaving a red mark on the stone, as is characteristic of many 
street shrines whose idols are anointed with vermilion. This last act, he affirms, is the "inauguration" of the "machine" (Figure 1). They then move away from the stone and observe from a distance and tells the father of Jaggu that after 15 minutes the investment will double. After a few minutes passersby notice the newly erected shrine and start making offerings to the stone. Peekay then compares the shrine with a tea-seller nearby, saying that to sell chai one needs to invest more capital and pointing to the many items needed to sell tea: the sugar, the tea, the thermos, the bicycle, etc. However, for the shrine, he points out, one only needs a stone and a red mark (tiki $\bar{a})$. He also explains that there is less effort involved as one does not need to call one's customers because they come on their own. The scene abruptly finishes with the father of Jaggu slapping Peekay for insulting him and his religion when Peekay reiterates that religion prays upon people's gullibility and fear.

Figure 1

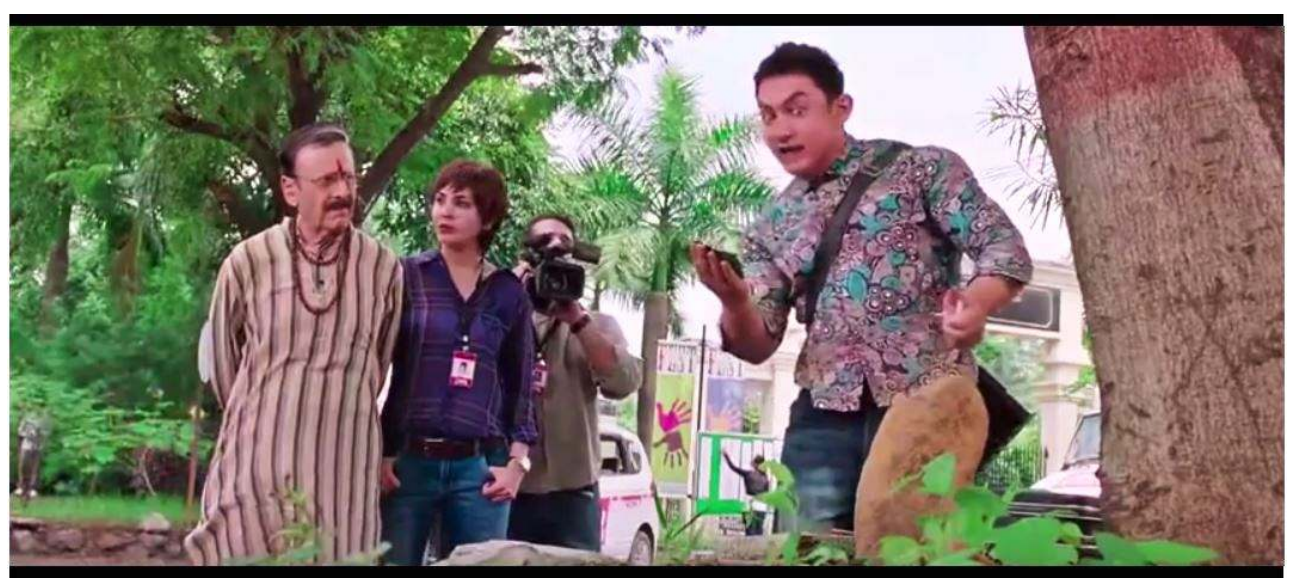

Screenshot of the scene in which Peekay performs the "inauguration" of the shrine.

Credits: PK (2014) Vinod Chopra Films(C)

2 While the satirical movie $P K$ uses humor and sarcasm to point to these non-devotional aspects, through the two case studies I have chosen in this article I also seek to elucidate cultural and socio-economic aspects that are entangled with the ritual and devotional aspects of religion, but that are rarely addressed in scholarship on contemporary Hinduism.

3 This article is primarily based on a brief session of six weeks of fieldwork conducted in early 2016 as part of a preparatory exploration for a larger ongoing research project on urban popular religion in India which focuses on wayside shrines. During this time, I conducted unstructured interviews with devotees and caretakers of several wayside shrines, and spend many hours in participant observation documenting the shrines presented here and many others. However, my interest in this phenomenon started as a photographic exploration of wayside shrines which began the first time I set foot in India in 2005. The reader might thus expect detailed ethnographic data from each site. However, due to the current project being in its early stages, I can only hope to be able to enrich the data in future publications. Despite the lack of an in-depth ethnography requiring years of immersion at each site, this article aims to present two meaningful examples of shrines located in the public space to illustrate aspects of these religious sites that are often mentioned only in passing when discussing contemporary Hinduism. 
Whereas, to advance my argument, I could have chosen other shrines among many that I have started to document in Pune, Maharashtra, these two cases work particularly well to demonstrate mechanisms in which religion can be instrumentalized for the erection of such shrines for more "mundane" objectives, as well as new modalities of practicing religion in the urban space. While one of the shrines is clearly a wayside shrine (the Mārutī Mandir), the other was a wayside shrine and has now become a regular temple (Corāñcā Ganpatī Mandir). The main reason for choosing one "wayside shrine" and one "temple" over two wayside shrines is that I would like to point to the conditions for, and particularities of, the transition process from a shrine to a formal temple. ${ }^{4}$

\section{Pune and its wayside shrines}

4 The city of Pune is known to be an important historical and cultural hub of Maharashtra, as well as one of the driving educational and fastest growing economical centers of India. ${ }^{5}$ Like Mumbai, it attracts a large and diverse number of people to the city, speaking different languages and embodying different cultures of India and abroad. Home to several multinational firms and groups, and second in the country as the host of several IT companies, Pune has increasingly grown to become an ethnically and culturally diverse place as well as one of the Indian cities with a high number of returnees from the Indian diaspora in a so-called "reverse brain-drain" (Chacko 2007). Additionally, the city has been a bastion for both Hindu nationalism and Hindu reform movements for the last two centuries, and thus, in many ways, it provides an ideal site to study social themes that are specifically local and, at the same time, pan-Indian or even global. This opens up for us the possibility of engaging with issues that concern the religious diversity of South Asia and at the same time reflecting on the way in which religions are embedded in politics of difference and identity formation in specific local social environments.

Wayside shrines can be found with various degrees of density nearly anywhere in Pune. However, the specific type of shrines may vary considerably depending on one's location in the city. It would be meaningful for a study on the wayside shrines of Pune to look closely at the physical landscape and the social-landscapes of the city. For instance, it would be important to understand the city's historical developments, the changes in infrastructure and its demographic distribution. Preston (2002), for example, demonstrates using historical records from before the occupation by the British in 1818 that temples-but more interestingly for us wayside shrines-already played an important role in the daily life of the city inhabitants and that these were carefully recorded by the Peśvā administration of the Maratha Empire. Thus some of these shrines have existed at least since Peśvā times (1713-1818) and have retained their informal character; others have evolved into institutionalized temples and yet others have been abandoned or disappeared. Today, the city core is still divided into roughly 17 peths or neighborhoods that were developed under the Peśvā rule. ${ }^{6}$ Traditionally certain groups settled according to caste and religion in these neighborhoods, and the old part of the city partly still reflects the architectural and the religioscape of the eighteenth and nineteenth centuries. However, while this still may be the case in a handful of examples for most of the shrines found today, the colonial rule, the subsequent urban development and the rapid modernization in neoliberal India as well as other events changed the city dramatically, altering not only the physical landscape, but also the social fabric and the spatial distribution of the shrines. Examples of such events and processes were, for 
instance, the rehabilitation settlements that evolved after the devastating floods of 1961, or the extremely rapid urbanization that migration from other parts of India and from rural areas into the city in the 1990s and 2000s (see, for instance, Shinde [2017]). Therefore, besides the old city center, where one can find many old shrines and temples still in use, in recent decades we can, in addition, observe a real boom of street-shrines that permeate the entire city's landscape. ${ }^{7}$ Environmental changes (such as the floods mentioned above and the changes of rivers and other bodies of water), human migration from rural to urban areas and exponential demographics ${ }^{8}$ are, of course, not the only aspects that have influenced this boom. Probably as important are the popularization of religious festivals (notably the Ganeś Utsav) ${ }^{9}$ and the mass reproduction technology: plaster cast, lithography, and other industrially produced goods used as religious paraphernalia. ${ }^{10}$

6 The wayside shrines we encounter in Pune are of various types, sizes and forms. These spaces are often ignored and forgotten by builders, civil engineers and architects as the city grows and expands, and, at the same time, are considered a nuisance by the municipal authorities who have to deal with illegal structures blocking the pavements. ${ }^{11}$ Perhaps the most visible in the city are the so-called "Mitra Mandals" or friend associations, a form of organization originally setup to organize the public worship of popular elephant-god Ganeśa particularly during the "Ganeś Utsav" which is a ten-day festival starting on the fourth day of the Hindu month of bhädrapada (August/Sept), known as ganeś caturthĩ. These "friend associations or societies" (as their literal name indicates) are usually male-exclusive athletic or politically oriented groups (although recently also women groups and mixed groups have emerged), often representing a geographical unit, usually the neighborhood. ${ }^{12}$ These groups might consist of only a few people or may have hundreds and even thousands of members. This festival goes back to the Peśvā times (Shinde 2014; Preston 1989), when the titular deity (kuladevatā) of the ruling Chitpavan Brahmins was Gaṇpatī. The Peśvās turned the worship of Gaṇpatī into a major festival in which idols of the god where collectively worshipped and carried through the streets. During the nineteenth century, within the socio-political context of the independence struggle from colonial powers, this festival saw a popular revival under the leadership of Bāl Gangādhar 'Lokmānya' Tilak, a freedom fighter who called for outdoor installations of Ganeśa idols and their submersion in local bodies of water during the ganes caturthī festivities as a form of resistance to colonialism. The temporary installation of public Ganpatī idols started as very location-specific phenomenon initially at the level of the neighborhood. These idols were meant to unite all the inhabitants of each neighborhood, and be visible for the enjoyment of the entire community (sārvajanik lit. "for all the people", although what was implicitly understood was Hindu community). Tilak used the festival as a neo-traditionalist platform for organizing speeches and cultural performances about social reform and anti-British propaganda and also to unify the Indian community at large (Cashman 1975). ${ }^{13}$ The festival emphasized unity as well as seeking progress and prosperity by seeking Ganpatî's grace to remove the obstacle of British rule.

7 Since then countless Mitra Mandals in all neighborhoods of Pune have emerged, sometimes creating permanent wayside shrines in order to worship Ganpatī all year long. However fascinating this phenomenon may be, this article will not be dealing with these types of shrines, even though they certainly could be considered prototypes for analyzing many of the wayside shrines of Pune. The embryonic form out of which some of the most 
famous temples in the city have evolved, such as the Śrimmant Dagduśeṭh Halvāī Gaṇpatī. ${ }^{14}$ Indeed, many of these "new" shrines follow this model of organization and practice and thus set an important precedent for the socio-political instrumentalization of religious spaces. ${ }^{15}$

Leaving the Mitra Mandals aside for a moment, in the following pages, I present the two examples that will serve as illustrations for my argument. The reason that these two examples were chosen, instead of two Mitra Mandals, is twofold: first, they exist outside the raison d'être of a communal enterprise such as the Mitra Mandals and rather go back (at least initially) to a single original patron; and second, because they illustrate particularly the non-religious uses and new modes of worship that occur at these sites. The first is a Hanumān/Mārutī shrine that is located on Pashan Road on the armament estate on the North-West side of the city; the second one is a Ganpati shrine on the Aundh Road in Khadki at the far outskirts of Pune (Figure 2). Both are located in areas that could be considered the suburbs of Pune that once were villages in their own right and were not considered part of the larger city until recently.

Figure 2

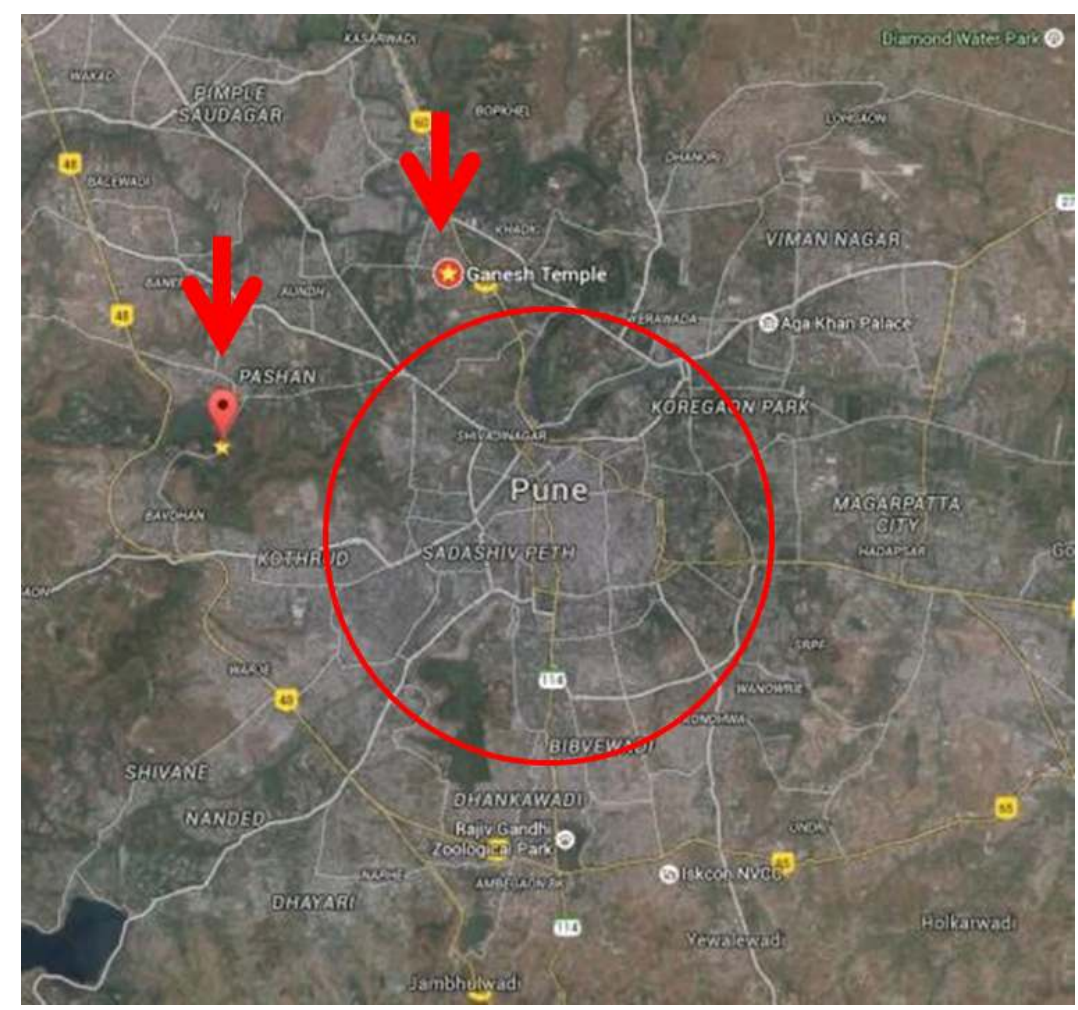

Map of Pune. The red circle shows the city center. The two shrines are located at the outskirts of the city.

Map data @2017 Google.

\section{Drive-thru Darśan - The Mārutī Mandir on Pashan Road}

9 I first came across this shrine when a friend of mine pointed out the shrine to me while driving with her through the area in 2011. She had noticed the shrine a few years back on 
her way to work when it had only been recently erected and was not yet famous. When I came back to Pune in 2016 specifically to work on the wayside shrines I asked her to take me back. The Mārutī Mandir ${ }^{16}$ is located on the pavement of a military area of the armament estate on Pashan Road. The area is sparsely populated since the land belongs to the government and other than the military housing complexes there are no legal or illegal settlements on this land. The fact that a shrine has been erected and has attracted enough devotees to survive, despite being on the pavement of a street controlled and managed by the municipality/military and with comparatively little foot traffic, is all the more remarkable.

10 I must confess that I have not yet been able to determine with any certitude the genesis myth of the shrine, as there are a few stories circulating of how the mandir supposedly emerged and a hegemonic narrative has not yet solidified. ${ }^{17}$ However, just a few years ago there was only a very simple structure erected by an anonymous devotee under a tree and a small Mārutī/Hanumān image was informally installed. There is thus no official "sacred site-narrative" (sthalapurāna) of any kind yet, except for floating oral stories. Apparently, people started reporting miracles granted to those who worshipped this image of Mārutī and soon a large Śani (Saturn) image carved out of a black stone was erected under the tree next to the Mārutī shrine. ${ }^{18}$

11 An elder devotee told me that there was a lieutenant named Kulkarni ${ }^{19}$ living in this military zone who had been having a particularly severe astrological phase known as sārhe sātī, a seven-and-a-half-year when Śani transits through his zodiacal signs bringing bad luck and illness to his life. The lieutenant was advised by an astrologer to pray to Hanumān in order to get rid of the evil influence of Śani. After praying to him every Tuesday and Saturday at this location (Hanumān's and Śani's respective auspicious week days) many of his problems vanished after just a few weeks. After this miraculous event, he was visited by Hanumān in a dream claiming that a shrine should be installed in his name at the entrance of the military compound where he was based. The lieutenant then installed a marble deity of Hanumān that he acquired (Figure 4). Nobody was able to tell me how the current large image of Śani was installed (Figure 5), but most devotees say that Śani was initially represented by an aniconic black stone..$^{20}$ 
Figure 3

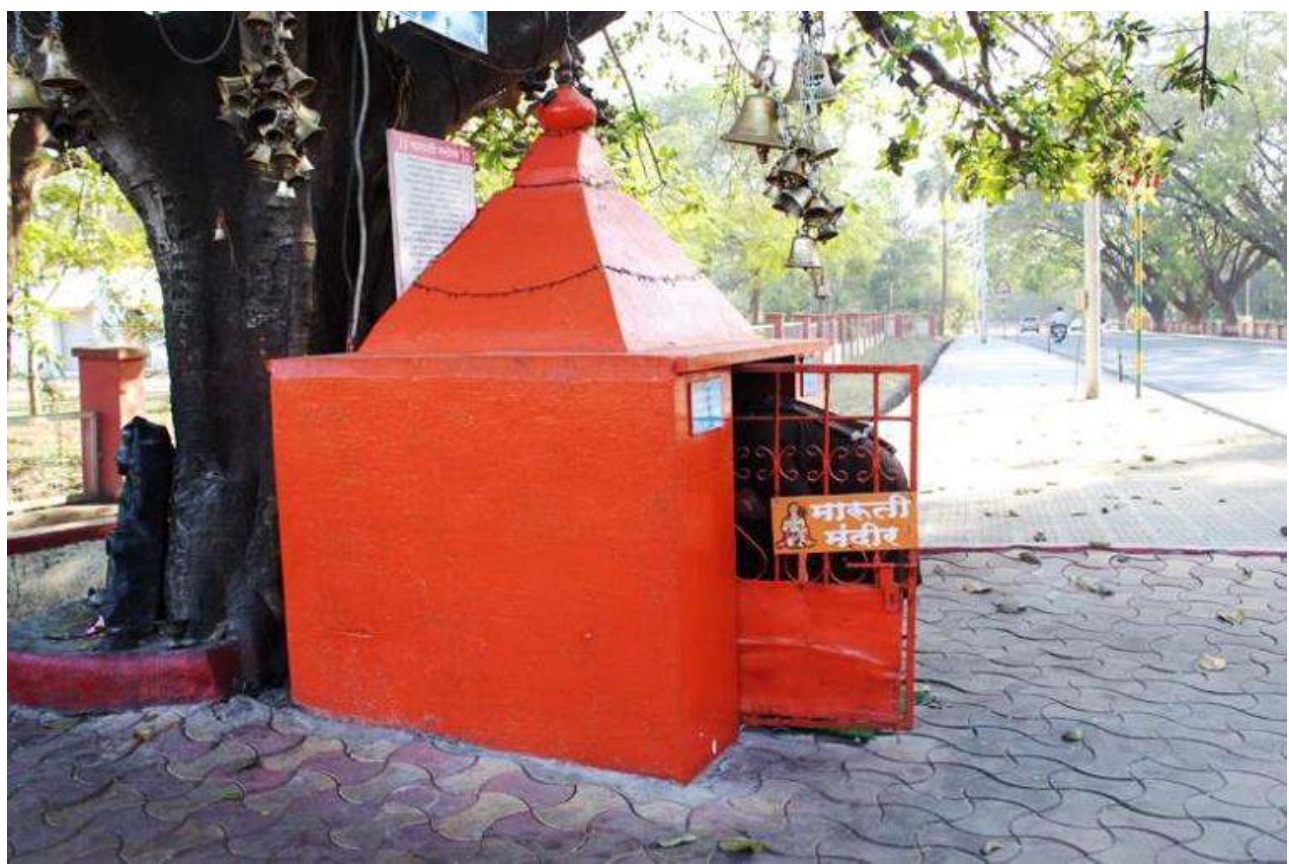

Mārutī Mandir with idol of Śani at the back of the temple on Pashan Road, Pune. Photo by the author.

Figure 4

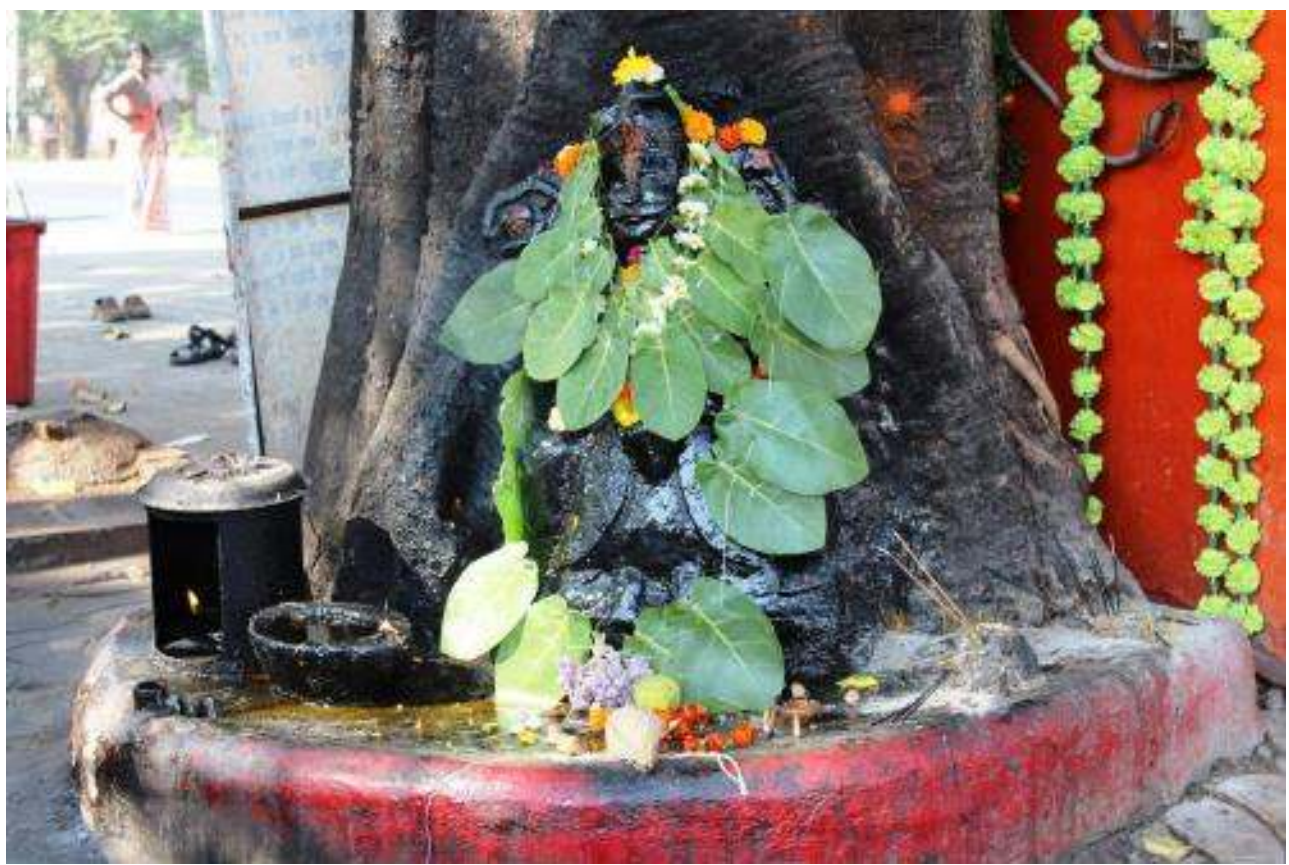

Śani covered with mustard oil, garlands of flowers, and ruĩ leaves at the base of the tree and at the back of the temple.

Photo by the author

12 According to a devotee, the current sculpted image of Śani appeared there years later after the initial image of Hanumān was installed. After some time, a more solid structure 
was erected to house Mārutī, and once the anthropomorphic image of Śani was installed in the open replacing the old aniconic stone, the shrine started to attract more devotees and gain popularity. ${ }^{21}$ Devotees began to attach bells of all sizes to the branches of the tree as well as other religious props, such as a large vinyl banner (approximately $2.00 \mathrm{x}$ $1.50 \mathrm{~m}$ ) inscribed with the famous Hanumān Cālīsa ${ }^{22}$ and devotional hymns were installed next to the tree by the caretakers of the shrine (Figures 6 and 8). According to the same elder devotee, the astrologer's own clientele also increased and he started recommending the shrine to his customers as an efficient place to appease Śani through Mārutī's ability to handle his dangerous force. More devotees started bringing bells to attach to the tree's branches and soon the tree was filled with them. In time, the shrine became more institutionalized and a board in English, Marathi and Hindi requesting that no offerings of cash be made or ornaments for the deity be gifted at the shrine was erected by the Estate Management Unit (which is governed by the Defense Research \& Development Organization [DRDO] that works under the Ministry of Defense).

Figure 5

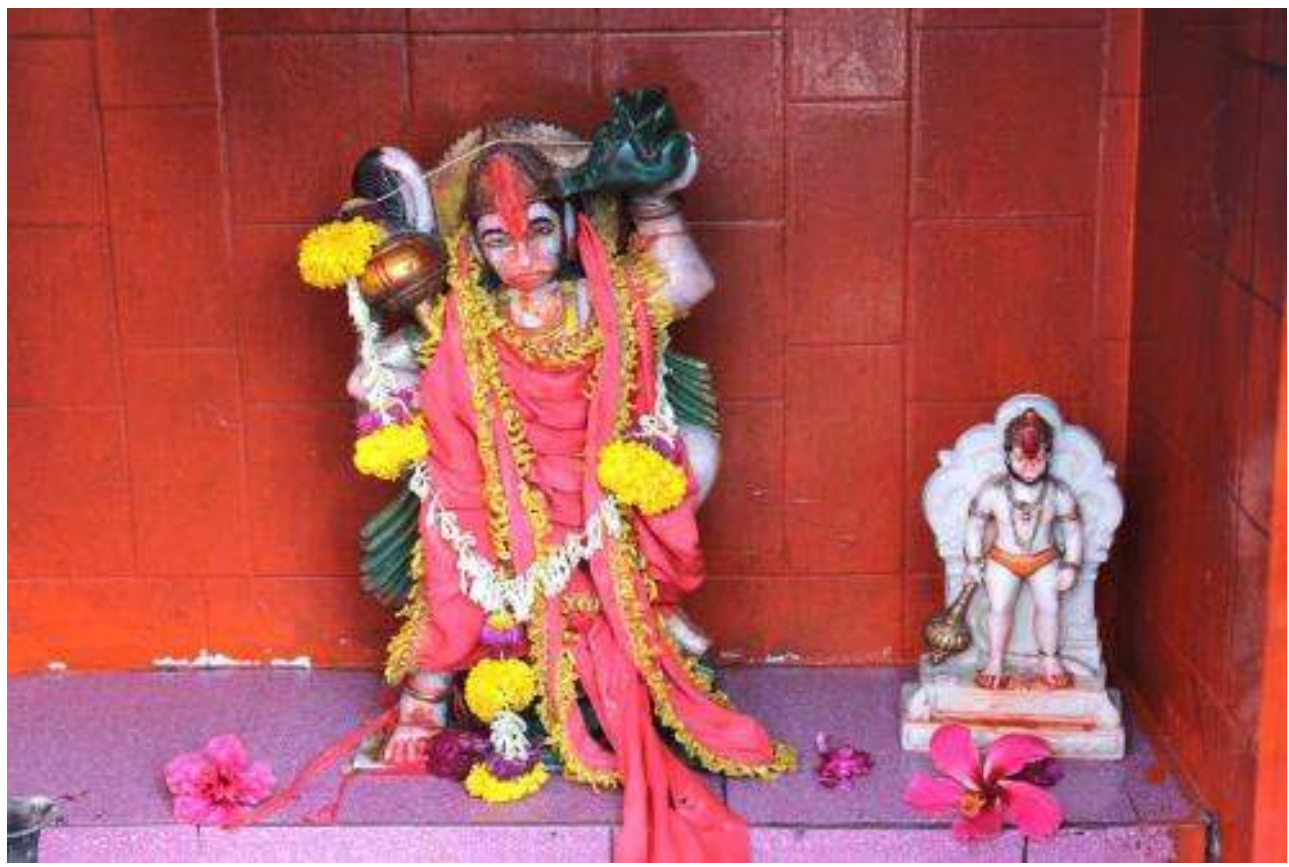

The two figures of Mārutī found in the temple's sanctum sanctorum.

Photo by the author.

It is also notable, that the shrine has no donation box (daksinina peți ), as is common of many urban shrines. At the time of writing there is still no official pūjäri officiating, and most devotees that come to the shrine perform their own rituals according to their knowledge, habitus or external recommendations from family members, gurus and other figures of authority. However, the two caretakers who are employed as watchmen of the entrance to the military estate, open and close the small door shrine every day. As they open and close the shrine they also perform a small pūja ritual, ensuring that nobody steals the Hanumān idol and that the shrine remains clean. I noticed that devotees who visit this shrine often imitate the rituals of other devotees and then seem to improvise creatively when making their own ritual procedures. ${ }^{23}$ There are, however, a few offerings that are commonly used in connection with both Śani and Mārutī, for instance, the widespread 
use of mustard oil ${ }^{24}$ (usually poured directly on the black stone of Śani) and the offering of loose leaves of the rui/arka tree (calotropis gigantea) which are often woven into garlands (ruīcī māll) and offered both to Mārutī and to Śani (Figure 5).

Figure 6

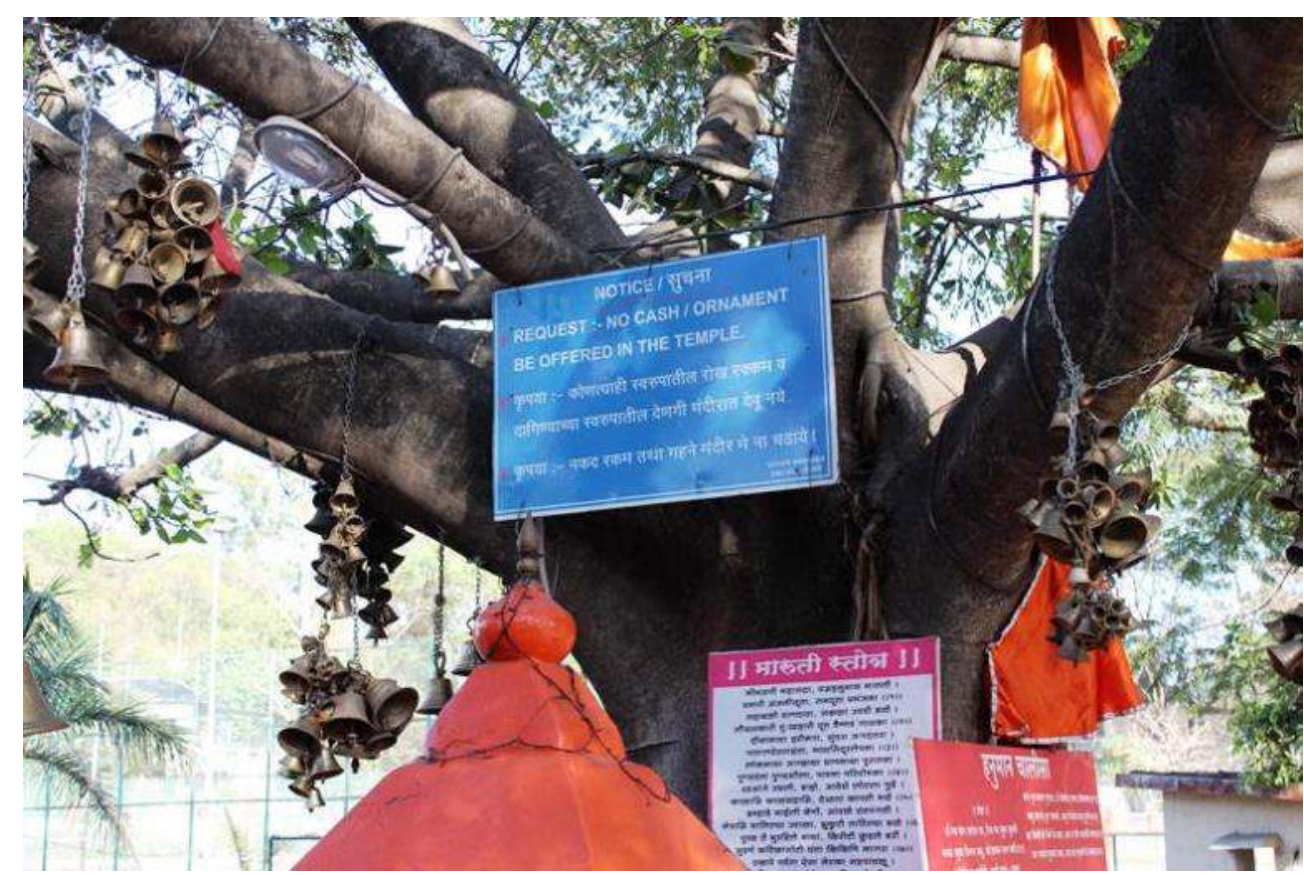

Notice Board from the EMU that reads "No Cash / Ornament be offered in the temple."

Photo by the author.

14 Now, whether the story of the shrine's origins is true or not (there are a few other narratives surrounding the emergence of the shrine), what is significant is that the shrine was erected very quickly in an area that one would hardly imagine a wayside shrine to become as successful as it is today. Even if this remains pure speculation, I would not be surprised if the shrine became even more successful and institutionalized. The reason for my speculation is that the shrine's location at the sidewalk of the avenue allows for quick darśan, while still ensuring a certain anonymity and ritual freedom. I believe that the rise in its popularity will soon be capitalized by the shrine's owners/caretakers and a sense of ownership will lead to further institutionalization. It is noteworthy that a certain level of institutionalization has already taken place. The boards placed by the EMU discouraging cash and even ornament donations to the shrine are testimony either to previous conflicts regarding the management of the donations or to the caretakers' concern that this might become an issue. Indeed, interviews with the devotees and caretakers of this shrine, as well as additional investigations, would reveal exactly what motivated the authorities to put up these boards. ${ }^{25}$ 


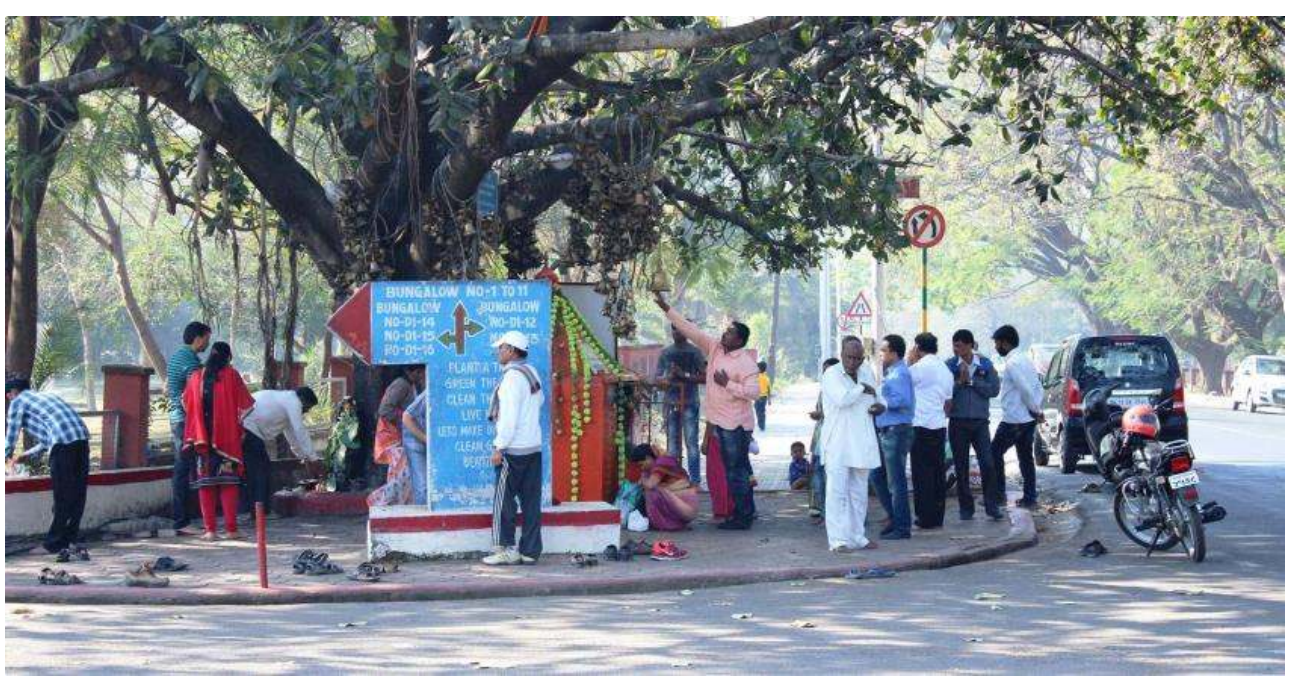

Devotees at the Mārutī Mandir on a Saturday morning.

Photo by the author.

The shrine is visited on a daily basis. However, most visitors come to pay their respects to Mārutī on Tuesday and Saturday when many flock to the shrine. The main characteristic of this shrine is what could be called "drive-thru" darśan. Here the motorized devotes make a quick stop at the shrine that takes between a few seconds to a few minutes, many without getting out of their vehicles (Figure 7). I observed a few men stop on their motorcycle, remove their helmet and while still on the vehicle make a quick gesture of respect (typically the añjali-mudrā, placing once palms together in salutation, followed by touching one's eyes or forehead and then the heart with the right hand). Other devotees would alight from their vehicles to make a quick prayer, ring one of the bells in front of the shrine and make a small offering (food, flowers, oil, or money, despite the sign); however, many did so while the engine was still on or while the driver waited in the car. The situation among pedestrians was similar. While many came specifically to the shrine to pay their respects, the darśan of the visitors I observed never took longer than a few minutes. ${ }^{26}$

On Saturdays the constituency of the visitors changes from mostly 'drive-thru' devotees to those who spend a bit more time at the shrine. On one particular Saturday, I found a few families with children of various ages. They sat down on the pavement while the children distributed fresh after having offered the food to Mārutī first. Another family had a thermos of chai which they distributed freely among the other devotees as prasād. The devotees shared with me that they do this on a regular basis at this particular shrine, especially if observing a vow (vrat) of a specific duration asking for a personal favor from Hanumān and perhaps most importantly to ask for help in appeasing Śani's evil influence. 


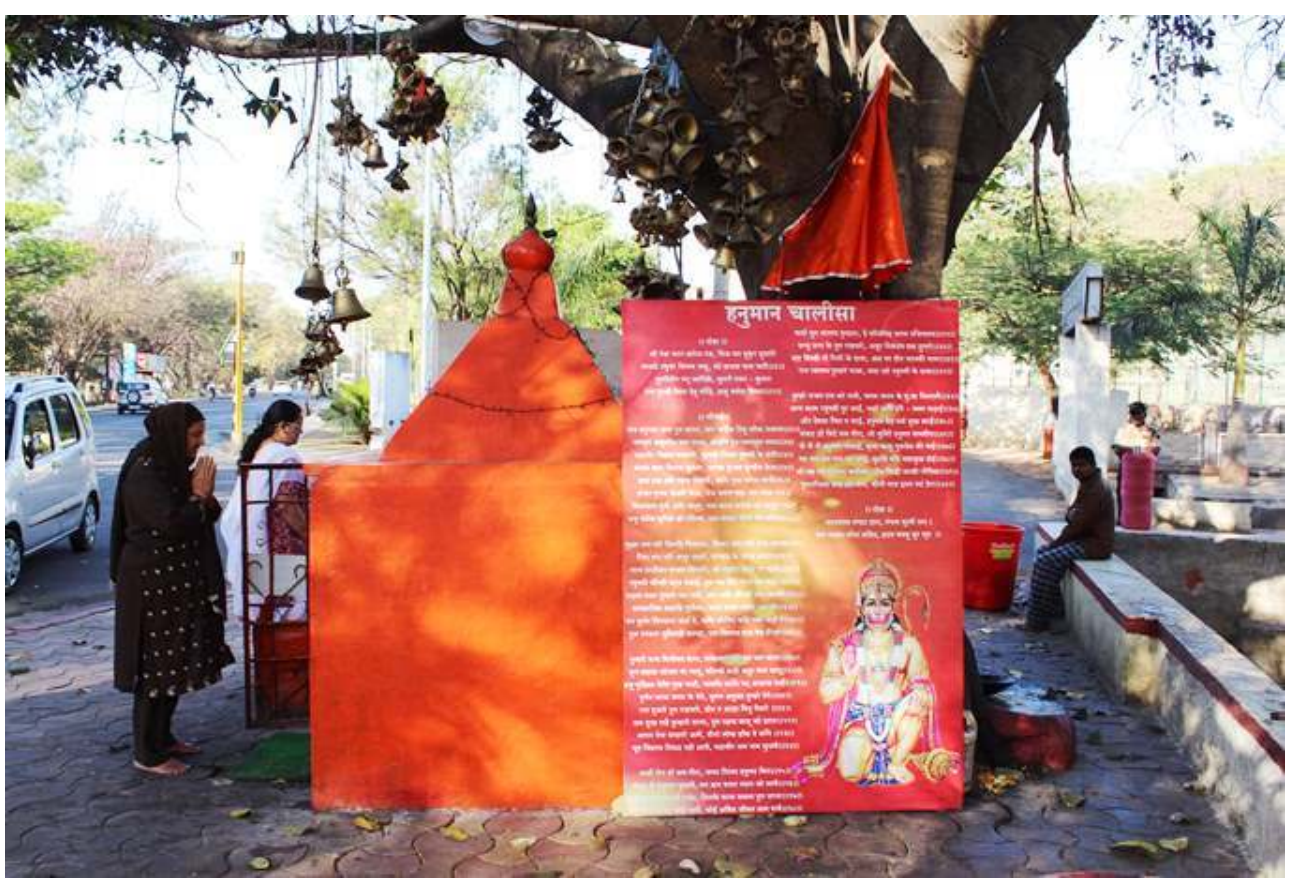

Female Devotee praying to Hanumān. Vinyl Board with the Hanumān Cālīsā.

Photo by the author.

Other people at the shrine sat around and chatted with each other, while others read the newspaper squatting on the pavement a few meters from the shrine. Others performed rituals of Hanumān and offered flowers, incense and mustard oil to Śani's idol. However, the four times I visited the shrine on both Saturdays and Tuesdays there was no priest, resident caretaker, or any other authority figure present at the shrine except for the guards stationed at the gate of the military compound a few meters from the shrine. These men objected to me taking photographs. Their objection, however, was apparently of me taking pictures in a military zone and not of the shrine itself. The shrine remains a relatively free space where one can see people of all backgrounds, age and economic status approach the shrine to express their devotion to Hanumān and Śani as they see fit. ${ }^{27}$ Besides the above-mentioned board discouraging devotees to make donations in cash/ ornaments to the deity there are no evident restrictions for visitors to the shrine. Indeed, the plurality of practices and the accessibility and simplicity attract a varied public that seems to support its ongoing success.

\section{From a Shed to a Palace - The Corāñcā Gaṇpatī of Khadki}

The second example is the temple called Śri Ganeś Sevā Mandir, popularly known as Corāñ $\bar{a}$ Ganpatī which means "the thief's Ganeśa" in Marathi. The genesis of this temple is similar, as it also started as a small wayside shrine dedicated to Ganeśa on a plot of land next to the M.M. Restaurant, which is owned by a man named Madhukar Mohandas Prabhakar, and which is located on the Aundh Road near the fish market of Khadki. As with the previous example, the temple is also located near a military area; however, it is 
not located on military land, but near to one of the fastest growing suburbs of Pune that is mainly inhabited by the upper middle-class, thus increasingly gentrifying the area. Khadki could be considered a town of the Indian Army base that employs a number of civilians in the two ammunition factories. The difference is that the area has a large number of civilian settlements as well as a popular market. However, as with the previous example there was not much religious activity (temples or other religious buildings) previous to the growth of this particular temple in this neighborhood.

The man responsible for the growth of the temple from a mere discrete wayside shrine to the temple it is today is Madhukar Mohandas Prabhakar, also known as Madhu Seṭh among the locals. He is some sort of local "Robinhood" ${ }^{28}$ who is mostly loved and respected among a considerable number of residents of the area. For instance, it is said that he used to donate money to the unemployed and needy; that he helped many patients to settle their hospital bills and even that he ran a big video center where he rented out movies at Rs 4 per video cassette. A police officer involved in the case against him said: "He has helped some people to such an extent that they literally worship him" (Dalvi 2011).

According to a resident quoted in the Sakal Times: "Madhu Sheth is like a god for us, he helps poor people in our area and always maintain [sic] good relations with everyone. We cannot believe that he is involved in such activities" (Kolhatkar 2011). Madhukar Mohandas Prabhakar also contested the civic elections from Aundh in 2002 as a candidate from the Bharipa Bahujan Mahasangh (a Dalit party) but lost to the Congress candidate (Corporation Elections 2002). He is known as the "millionaire burglar" in the media and has several bungalows and apartments, as well as owning the above-mentioned restaurant next to the temple on Aundh Road.

Figure 9

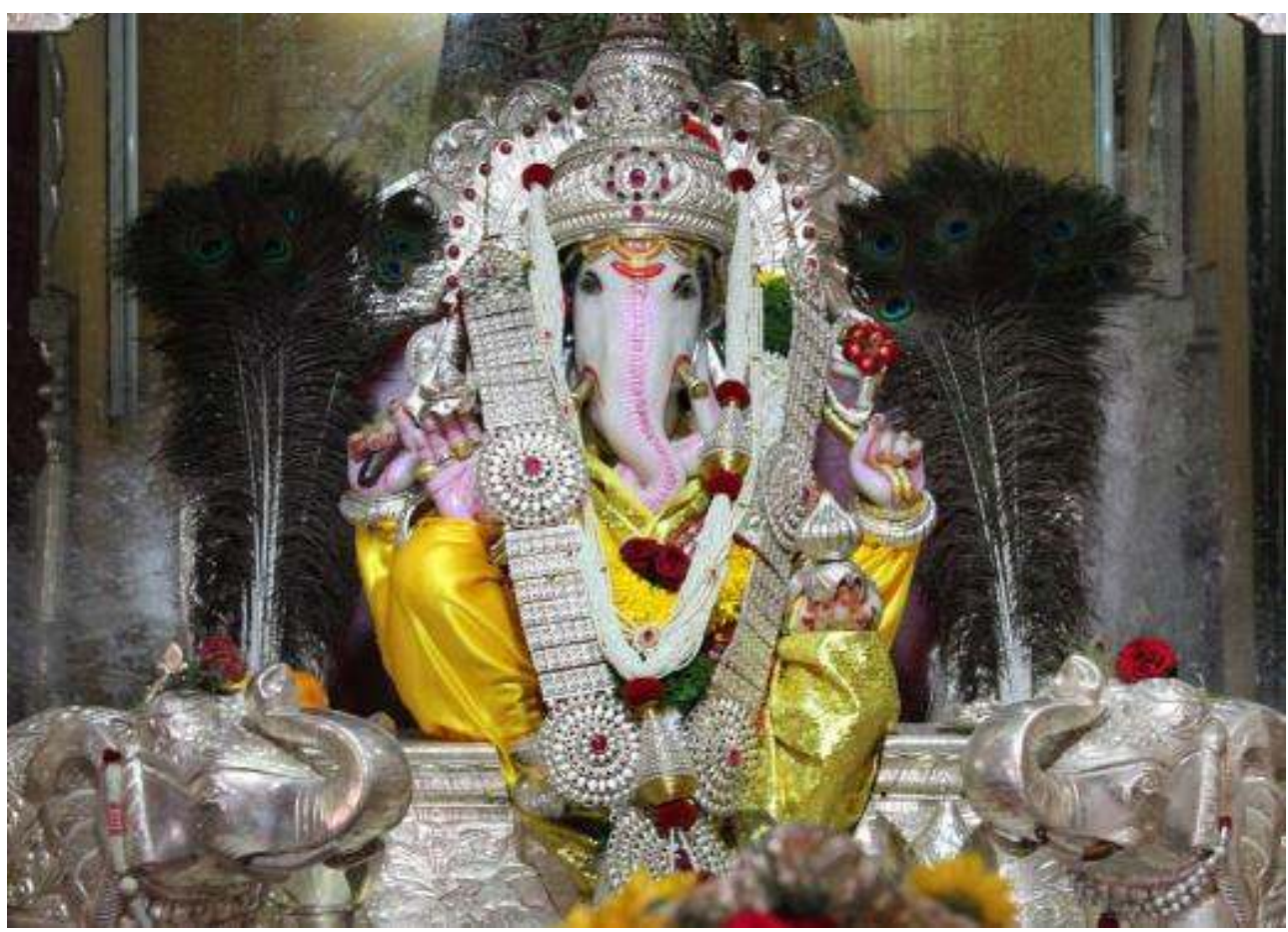

The decorated image of Ganeśa at the Śrī Ganeś Sevā Mandir in Khadki, Pune.

Photo by the author. 
Many locals remember how the temple grew very quickly from just a simple shed at the side of the road hosting a simple idol of the elephant-headed God to the grand temple it is today. According to a vegetable seller, Madhu Śeth felt protected by the god that was on the street of his ancestral land and decided to move it from the street into his plot and build him a worthy temple there. The temple was initially a simple building when it started in the 1990s. However, it very quickly grew into a more lavish temple from the cash that flowed from the burglar's own pockets and the support of local devotees. According to Rajaram Lole, the security guard at the temple, it was Madhu Śțh who hired artists from Rajasthan to do the exquisite marble and metal work. The current marble image of Ganeśa (Figure 9) was ritually installed during the inauguration of the new temple structure, which replaced the old Ganeśa that used to house the humble image of the wayside shrine. Nowadays, the temple is guarded by CCTV and watchmen who regularly police the grounds making sure that no one steals from the temple and that people behave properly. There is also a curious board that reads: "Devotees who wish to donate any gold or silver ornaments should kindly deposit it with the watchman on daily at the table and take receipt of the same without fail. Do not deposit the ornaments with anybody else other than the watchman deputed at the table counter." (Figure 10) The temple is clearly not only a place to ostensibly display the riches of the Prabhakars, or even as some assume "to laundry black-money", it is also a place for the locals to meet, socialize and express their devotion and commune with Ganeśa. Local children also enjoy going to the temple which even has a playground (Figure 11).

Madhu Śeț was caught robbing a property in Mumbai in May 2011 and has been in jail ever since. However, the temple has long been officially registered with the local authorities as a "Hindu temple trust" under surveillance of the Charity Commissioner, Pune, as per the Bombay Public Trusts Act of 1950. It is a very active trust in charge of all the activities and management of the temple. The wife of Prabhakar declared that the temple was not built with the money from the robberies, but from the earnings from the restaurant (Gurjar 2011). 
Figure 10

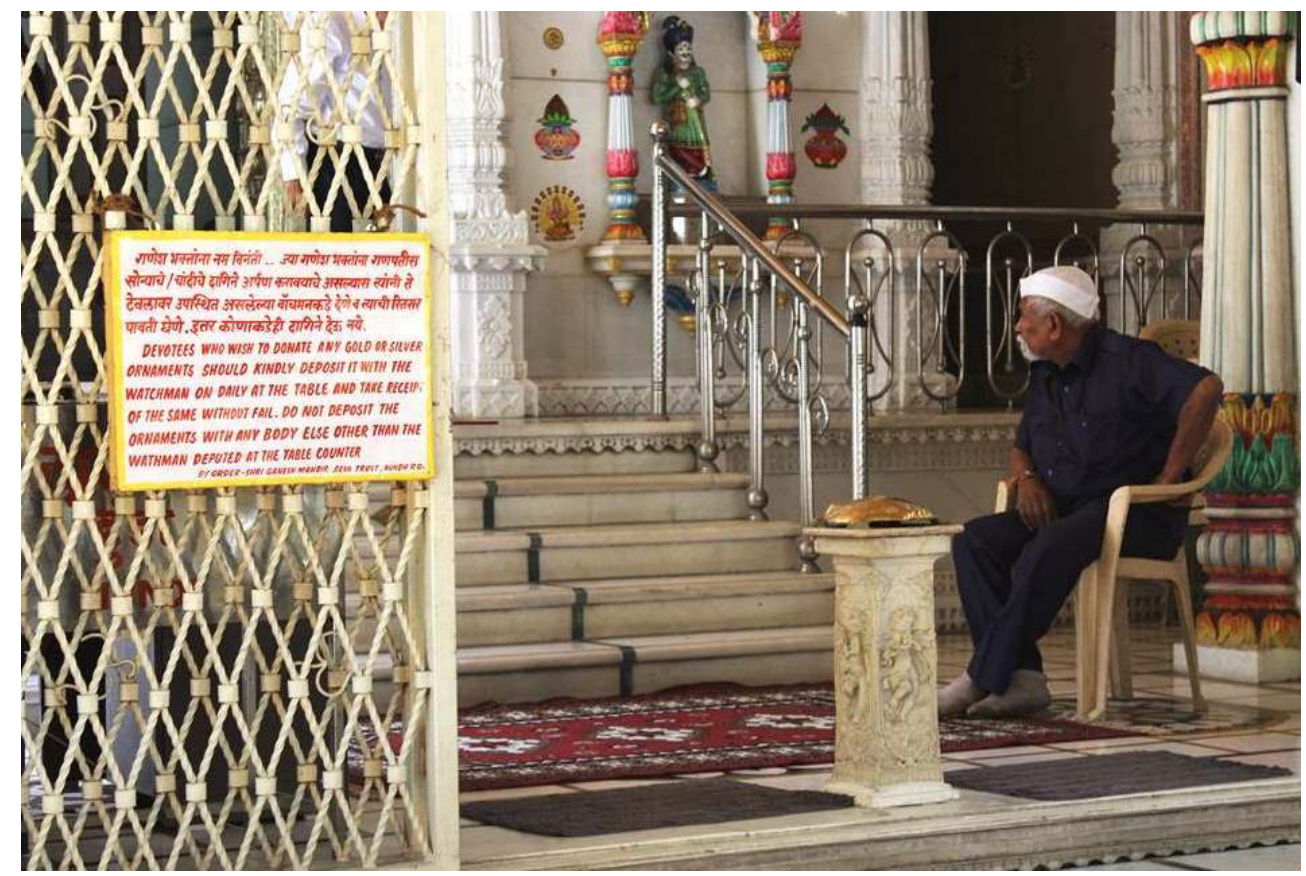

Board and watchman of the Śrī Gaṇeś Sevā Mandir in Khadki, Pune.

Photo by the author.

Figure 11

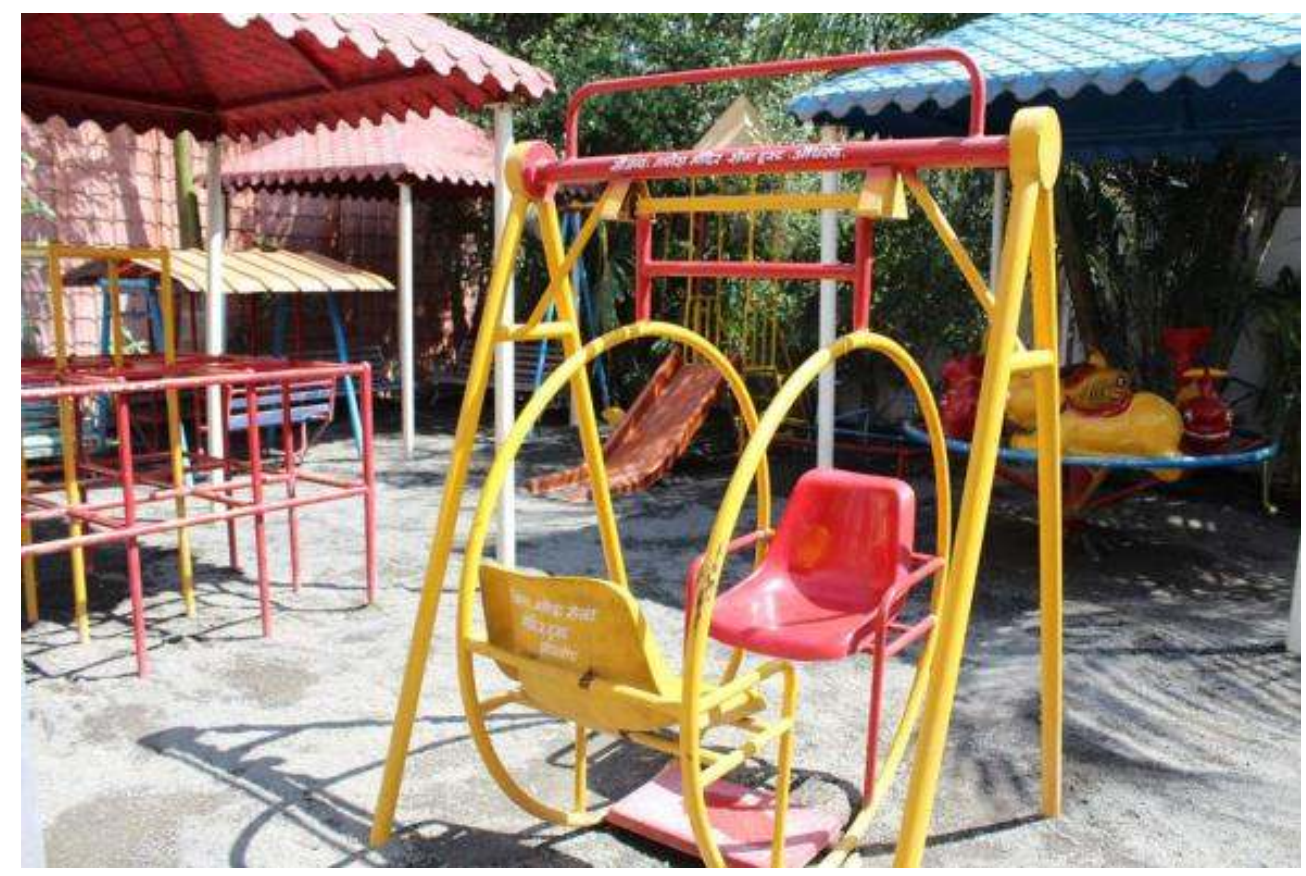

Playground at the Śrī Ganeś Sevā Mandir in Khadki, Pune.

Photo by the author.

In February 2016, when I was last there, the temple celebrated 25 years since its foundation (albeit its modest origins) and had two days of big celebrations including a 
grand distribution of food, blood-donation camps, fire ceremonies (homas), performances of devotional songs by chanting female groups and more (Figures 12 and 13).

There are of course opposing views and voices on what is happening here. Some people I talked to say that the Corāñcā Ganpatī, like most temples, is not free of hidden and notso-holy agendas, such as the laundering of money and a way for Madhu Sețh and his accomplices to evade taxes. Others say it is just a way to "save face" and gain popularity among the neighborhood and the general public. This is not a unique case, since gūndās (gangsters or criminal leaders) are well-known for leaving behind institutions such as this one as part of their legacy. ${ }^{29}$ While it would certainly be inappropriate to suggest any illicit activities at the temple or connected to it from the data I have collected so far, the fact that the temple is popularly known as "the thief's Ganpatī" indicates that many devotees know of Madhu Śeth's illicit past and the temple's connection to a patron whose past profession has led him to remain behind bars.

Figure 12

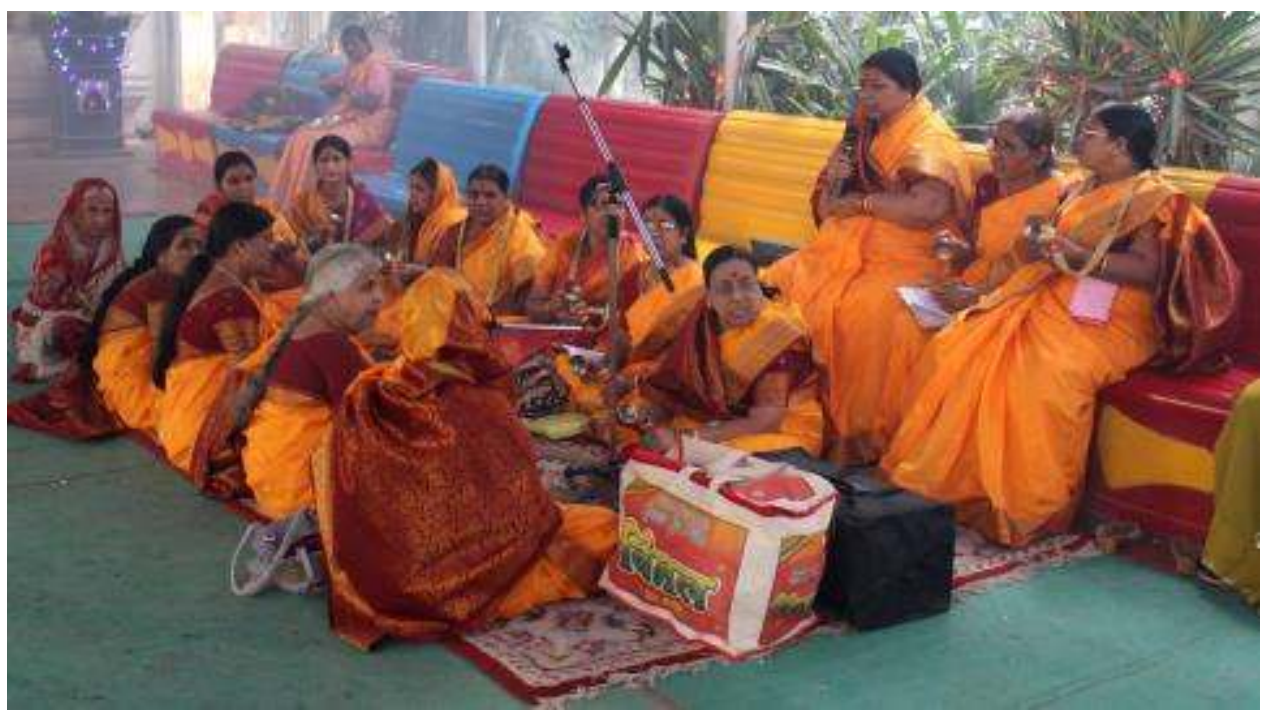

Group of female singers during the 25 anniversary celebration of the temple.

Photo by the author. 
Figure 13

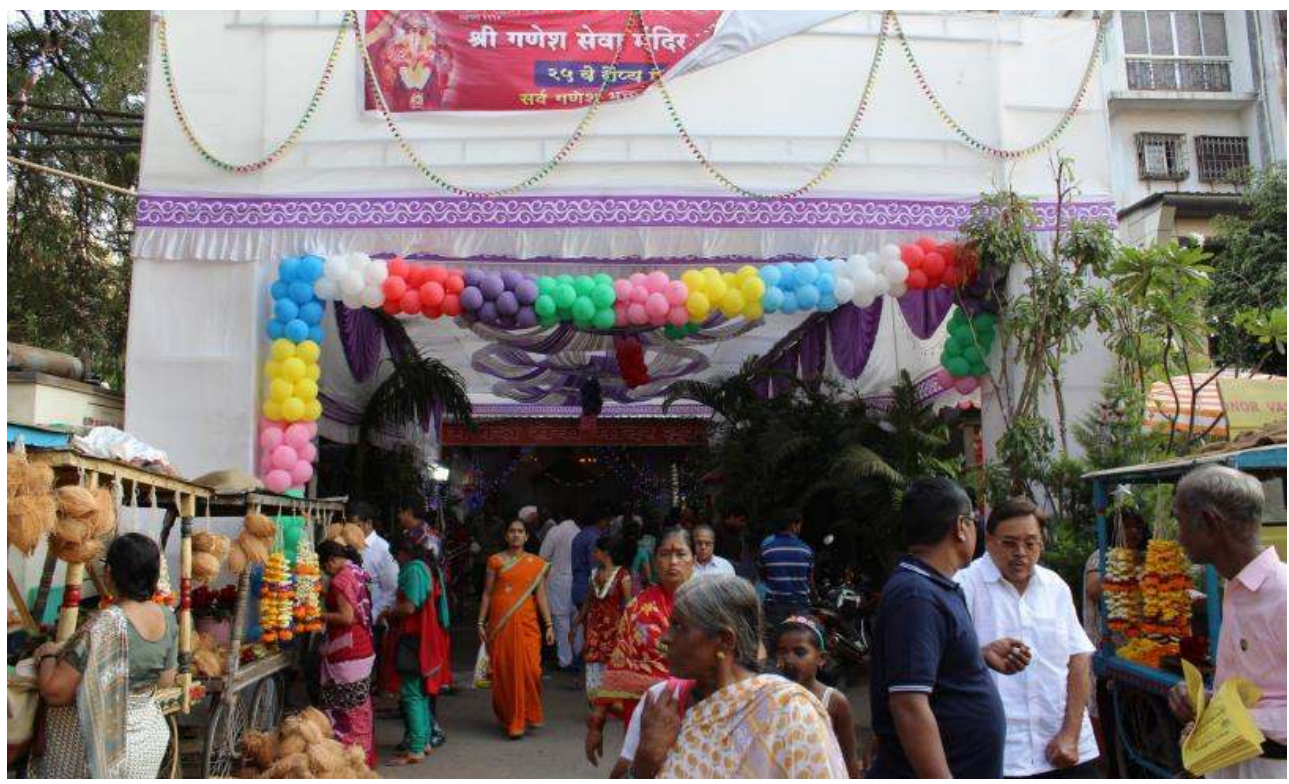

Stands with flowers, coconuts and other ritual items at the entrance of the temple.

Photo by the author.

\section{Conclusion}

This modest contribution presented two contrasting examples of wayside shrines to argue that these spaces point us to aspects and modes of religion that present new ways of emerging, unfolding, and converging in the urban space. The first example presented was a tiny shrine occupying a patch of pavement on Pashan Road which is steadily growing in popularity; and the other wayside shrine turned into an extravagant temple in just a few years. According to the locals, there used to be hardly any public religious activity in these areas prior to their appearance, thus these phenomena exemplify the significant popularity of these types of spaces for religious practice. Therefore, one could argue that these shrines' appeal is strong enough not only to defy their legality and to attract devotees to little populated areas. One could also suggest that these shrines are fulfilling the religious need of the population in the area and monopolizing the religious fervor in an area that otherwise does not have a place of worship. Moreover, one could see these shrines-as Bellamy (2014) has for Śani shrines in Delhi-as sites where changing notions of a new urban religious economy become evident, and where traditional practices and religious concepts morph to suit the urban social space of the everyday. ${ }^{30}$ However, there is more to the story than this: several of my interviewees suggested that the fact that these shrines can easily be installed lends itself to motives other than devotion and that the erection of these shrines is one of the favorite methods of "land grabbers" and "encroachers" to appropriate land; or to mask other illegal activities, including the trafficking of drugs and money-laundering or simply as an alternative form of begging. While no illicit activities as such were observed at these shrines, and it would be irresponsible on my part to claim criminal connections with the information at hand, many scholars who have worked on the subject have noted that these shrines support similar illegal or at least informal economies (Kalpagam 2006; 
Sekine 2006; Bellamy 2014; Shivam 2016). One could therefore claim that there is at least some truth in Peekay's assessment of these shrines as a business model that feeds off the devotion of innocent people. However, to reduce them to their political affect or the economic advantages exploited by their owners would be to ignore their role as safe meeting points for their communities, the constitution of resource networks, their mobilization of affective ties to the locality, and even the facilitation of social mobility and power ${ }^{31}$ All of this is made possible through ritualized charities, performances and services. Indeed, many of these shrines (as I alluded to with the brief example of the "Mitra Mandals") are the axis mundi of "social clubs" with different aims varying from political indoctrination, to environmental activism. In other cases-as Charlotta Østerberg and others have shown in this volume-these shrines provide a safe haven for women, beggars and other vulnerable people and even attract outside visitors.

One could regard urban wayside-shrines as the embryonic form of the franchised temple, as some have done before (see Elison and Kent in this volume). Here too, we could consider these two cases as vivid examples of the institutionalization processes "in the making" in which solidifying practices and discourses at the shrine are at work. While this may be an obvious possibility, as we saw with the last example, namely a sort of evolutionary process that struggles from a kaccha to a pakka state (as William Elison would say; a process that Jürgen Schaflechner would call "the solidification of tradition" [Schaflechner 2017]), it is certainly not the only possibility. We can observe processes of institutionalization already happening at these places: the street-shrine that starts policing the ritual offerings made to the deity, and the recommended prayers for the devotees in the first example. The second example, being a fully-fledged temple, has even gone further: the official status and hierarchical organization, the annual festivals, blood donations camps, the installation of CCTV, and a children's playground. In other words, we can clearly observe the process from a kaccha wayside shrine to a fully pakka temple. But, how do we account for the myriad of wayside shrines that not only never become a "proper" temple, but which, on the contrary, we could consider a necessary antithesis to established temples? Regarding the first example presented here, will it ever become a pakka temple, like the Corāñaa Gaṇpatī? As the creative subversion of the established socio-religious order and its structures of power these spaces (could we call them third spaces? Cf. Bhabha [2004]) serve as sites of resistance and negotiation which offer possibilities that established temples do not, ${ }^{32}$ and can also serve marginalized communities in specific localities fostering practices that are not necessarily welcomed in such sanitized or ideologically charged spaces. The shrines fill a vacuum that is not just an easy business model for morally questionable individuals, as Peekay suggests in the movie, but rather a platform that fulfils a series of needs at the core of the everyday life of caretakers, sponsors and devotees. The street-shrine reveals among other things the blurred boundaries between the rural and the urban, the sacred and the mundane, the institutionalized and the popular, and, of course, the legal and the illegal.

Sood, Megha. 2011. “Pune’s Own 'Millionaire Thief' Lands in Mumbai Police Net.” The Indian Express, May 17. Retrieved August 26, 2017 (http://archive.indianexpress.com/news/pune-sown--millionaire-thief--lands-in-mumbai-police-net/791825/). 


\section{BIBLIOGRAPHY}

Bellamy, Carla. 2014. "The Age of Śani in Modern Delhi." Nidan: International Journal for Indian Studies 26(1):22-41.

Bhabha, Homi K. 1994. The Location of Culture. London: Routledge.

Bhatti, Harvinder S. 2000. Folk Religion: Change and Continuity. Jaipur: Rawat Publications.

Blom Hansen, Thomas. 2016. "Recuperating Masculinity: Hindu Nationalism, Violence and the Exorcism of the Muslim 'Other.” Critique of Anthropology 16(2):137-72.

Brackett, Jeffrey M. 2004. "Practically Hindu: Contemporary Conceptions of Hanumān-Mārutī in Maharashtra." PhD dissertation, Faculty of Arts and Sciences, University of Pittsburgh, Pennsilvania.

Cashman, Richard I. 1975. The Myth of the Lokamanya: Tilak and Mass Politics in Maharashtra. Berkeley.

Cerulli, Anthony and Caterina Guenzi. 2016. "Mineral Healing: Gemstone Remedies in Astrological and Medical Traditions." Pp. 73-93 in Soulless Matter, Seats of Energy: Metals, Gems and Minerals in South Asian Religions and Culture, edited by F. M. Ferrari and T. Dahnhardt. Bristol, CT: Equinox Publishing Ltd.

Chacko, Elizabeth. 2007. "From Brain Drain to Brain Gain: Reverse Migration to Bangalore and Hyderabad, India's Globalizing High-tech Cities.” GeoJournal 68(2-3):131-40.

Corporation Elections. 2002. Retrieved August 26, 2017 (http://www.punediary.com/html/ pmc_electons1.html).

Dalvi, Vinay. 2011. "Rich Catch: Cops Stumble upon Millionaire Burglar with 9 Flats, 3 Bungalows." Mumbai Mirror, May 17. Retrieved August 26, 2017 (https:// mumbaimirror.indiatimes.com/mumbai/other//articleshow/16127858.cms).

Elison, William. 2014. "Sai Baba of Bombay: A Saint, His Icon, and the Urban Geography of Darshan." History of Religions 54(2):151-87.

Gurjar, Kaumudi. 2011. “'Robbing Hood' Learns from Victims' Errors.” Mid-day.com, May 20. Retrieved August 16, 2017 (http://www.mid-day.com/articles/robbing-hood-learns-fromvictims-errors/122477).

Hansen, Thomas Blom. 1996. "Recuperating Masculinity: Hindu Nationalism, Violence and the Exorcism of the Muslim 'Other.” Critique of Anthropology 16(2):137-72.

Hirani, R. 2014. PK. Film. India: Vinod Chopra Films.

Kalpagam, Uma. 2006. "Secularism, Religiosity and Popular Culture: Chennai's Roadside Temples." Economic and Political Weekly 41(43/44):4595-600.

Kantak, M.R. 1990. "Development of Pune (Poona) Before its Urbanization (2 ${ }^{\text {nd }}$ Century BC to 1707 AD)." Proceedings of the Indian History Congress 51(1):846-52.

Kaur, Raminder. 2002. "Martial Imagery in Western India: The Changing Face of Ganapati since the 1890s." South Asia: Journal of South Asian Studies 25(1):69-96. 
Kaur, Raminder. 2005. Performative Politics and the Cultures of Hinduism: Public Uses of Religion in Western India. London: Anthem Press.

Kolhatkar, S. 2011. “Khadki's Robinhood who Burgled Mumbai Homes.” Sakal Times, May 20.

Larios, Borayin and Raphaël Voix. 2018. "Wayside-shrines in India: Prosaic and Defiant Religiosity.” South Asia Multidisciplinary Academic Journal 18. Retrieved May 22, 2018 (https:// journals.openedition.org/samaj/4546).

Lohokare, Madhura. 2017. "Neighborhood Associations in Urban India: Intersection of Religion and Space in Civic Participation." Pp. 167-83 in ARI: Springer Asia Series, vol. 5, Place/No-Place in Urban Asian Religiosity, edited by J. P. Waghorne. Singapore: Springer Singapore.

Lutgendorf, Philip. 2007. Hanuman's Tale: The Messages of a Divine Monkey. Oxford, New York: Oxford University Press.

Marchetto, Monia, and Manuel M. Hoefer. 2016. "From Iron to Sapphire: Indian Myths and Rituals about Saturn, the Implacable Lord of Celestial Spheres." Pp. 51-71 in Soulless Matter, Seats of Energy: Metals, Gems and Minerals in South Asian Religions and Culture, edited by F. M. Ferrari and T. Dahnhardt. Bristol, CT: Equinox Publishing Ltd.

Piliavsky, Anastasia. 2015. "Patronage and Community in a Society of Thieves." Contributions to Indian Sociology 49(2):135-61.

Preston, Laurence W. 1989. The Devs of Cincvad: A Lineage and the State in Maharashtra. Vol. 41. Cambridge: Cambridge University Press.

Preston, Laurence W. 2002. "Shrines and Neighbourhood in Early Nineteenth-century Pune, India." Journal of Historical Geography 28(2):203-15.

Qadri, Monisa, and Sabeha Mufti. 2016. "Films and Religion: An Analysis of Aamir Khan's PK." Journal of Religion \& Film 20(1):1-29

Olivelle, Patrick. 2010. “The Temple in Sanskrit Legal Literature.” Pp. 191-204 in Archaeology and Text: The Temple in South Asia, edited by H. P.Ray. Oxford: Oxford University Press.

Schaflechner, Jürgen. 2017. Hinglaj Devi: Identity, Change, and Solidification at a Hindu Temple in Pakistan. New York: Oxford University Press.

Sekine, Yasumasa. 2006. "Sacralization of the Urban Footpath, with Special Reference to Pavement Shrines in Chennai City, South India." Temenos 42(2):79-92.

Shinde, Kiran. 2014. “Ganesh Festival: A Ten-day Extravaganza; A Life Full of Meanings.” Pp. 2338 in Routledge Advances in Event Research Series, Rituals and Traditional Events in the Modern World, edited by J. Laing and W. Frost. London, New York: Routledge.

Shinde, Kiran A. 2017. "Disruption, Resilience, and Vernacular Heritage in an Indian City: Pune after the 1961 Floods." Urban Studies 54(2):382-98.

Shivam, Pushkal. 2016. "The Space of Street-side Religiosity: Miniature Shrines in Chennai." Economic and Political Weekly 51(4):56-62.

\section{NOTES}

1. I would like to thank all the participants of the ECSAS 2016 panel "Street-shrines: religion of the everyday in urban India" who contributed with their questions and feedback to this paper. In particular my gratitude goes to Patrick McCartney who read an earlier version of this piece and 
corrected my English, Raphaël Voix, and the anonymous reviewers from SAMAJ whose comments significantly improved this article.

2. https://youtu.be/3aBJ_DlVWsY?t=1h41m19s accessed on August 23, 2017.

3. Pān is a preparation combining betel leaf with areca nut and sometimes also with tobacco that is chewed broadly in South Asia. It strongly colours the mouth with a brownish-red colour. After chewing pān the remains are either spat out or swallowed. In the movie Peekay learns to chew $P \bar{a} n$ from a prostitute, thus adding to the transgressive character of the scene.

4. Here the term mandir is used for both structures, thus the local terminology can be somewhat misleading. While both structures "house" the deity, the Corāñcā Gaṇpati is clearly a formal temple, whereas the Mārutī Mandir has all the characteristics of a "wayside shrine": its main deity is "immediately adjacent to a public path, visible from it and accessible to any passerby" (Larios and Voix 2018). For an extensive discussion on the terminology of "wayside shrine" versus "temple" see the introduction to this volume (Larios and Voix 2018).

5. According to India Today, based on the United Nations World Economic Situation and Prospects Report of 2016, "Pune is the fastest growing city in India in terms of economic growth. Pune has seen a 317 percent growth in the number of multi-millionaires in the last 10 years." https:// www.indiatoday.in/education-today/gk-current-affairs/story/fastest-growing-

economy-305186-2016-01-23 accessed September 30, 2017.

6. The oldest of the neighbourhoods, Kasba Peth, hosts the oldest Ganpati temple around which the original village of Kasba Pune was built (see Kantak 1990:847).

7. While there are no published studies on this boom, architects, civil engineers, scholars and other informants who have been living of the city of Pune all their lives have shared with me in private communications that they have seen a massive increase in these shrines in the last two decades.

8. For the last 40 years the decadal growth rate of the city has been at least $40 \%$ and it's estimated that population will hit 5.6 million by 2031 if this trend continues. According to some estimates based on the census of 2011 the city has a population density of 5,600 people per square kilometre. http://worldpopulationreview.com/world-cities/pune-population/ accessed August 23, 2017.

9. A brief discussion of this festival will follow below.

10. Elison (2014) has written an excellent piece on the figure of Sai Baba and his urban shrines where he addresses this issue. See also his forthcoming book.

11. In 2011 the Bombay High Court had already ordered the demolition of illegal religious structures erected after September 29, 2009 across the state. Despite a government resolution (GR) stating that these structures should be removed, the Bombay High Court had to remind the authorities of their duties on several occasions. According to the Times of India the removal of these shrines faced opposition from politicians and corporations. http:// timesofindia.indiatimes.com/city/pune/action-against-illegal-religious-structures-grinds-to-ahalt-to-resume-in-september/articleshow/58980832.cms accessed August 29, 2017.

In March 2016, in the city of Pune alone the district committee and the anti-encroachment department of the Pune Municipal Corporation listed 905 illegal religious structures which were constructed prior to 2009. According to the Indian Express "of these, it has been decided that 677 structures would be regularised, while a decision regarding 190 structures that have to be either demolished or shifted is pending." http://indianexpress.com/article/cities/pune/677-illegalreligious-structures-to-be-regularised-35-demolished/ accessed August 29, 2017. However, many of the shrines after being demolished were rebuilt shortly after.

12. By the word "neighbourhood" I mean not only the traditional peths or "wards" of the old city, but units of different people that can be as small as a group of a few people living in a particular street. There can be more than one communal Ganpatī in a particular area. In fact, each family 
has its own idol at home which is also immersed in a body of water on the final day of the festival.

13. However, it should also be noted that Mitra Maṇals have also been instrumentalized since their beginning for political purposes, functioning as sort of indoctrination cells which breed a national majoritarianism that is not truly inclusive (sārvajanik) in character and have played a major role in communal conflicts, for example in the riots of Mumbai in 1992 and 1993. See, for instance, Hansen (1996) and Kaur (2002).

14. For more on the Mitra Maṇdaḷ and the Śrīmant Dagḍuśețh Halvāī Gaṇpatī see Kaur (2002), Shinde (2014) and Lohokare (2017).

15. It is important to note that many of the wayside shrines of Pune were initially not necessarily governed by Mitra Mandals, and that many shrines in the city were erected previous to the creation of this institution by Lokmānya Tilak. Indeed, the neighbourhood shrines often mirror instead the organisation of village shrines. For some of the old shrines dedicated to Mārutī in the city see Brackett (2004:75-117).

16. Mārutī is the more common name of Hanumān used in Maharashtra. Mārutī is a patronym which is translated as "son of the wind", or son of Marut, a name for the Vedic god Vayu. The Sanskrit name is spelled Māruti (short i). However, since the temple itself spells its name as Mārutī (long i) as it is common in Marathi, I have decided to use the former throughout the article. For more on the name Mārutī see Brackett (2004:7-10). The same goes for Ganpatī instead of Ganapati. The fact that the shrine is termed "mandir", a term usually translated as "temple", should come as no surprise when dealing with shrines. While the term is very often used to designate larger and more institutionalized temples, it is also very often employed for smaller wayside shrines such as this one, both in Maharashtra and in other parts of western and north India. In fact, as Olivelle (2010:195) has remarked, the first mention of "temples" (devāyatana) in Sanskrit literature also referred to rather smaller structures located along roads. For a theoretical discussion on the semantic problems of the terminology, please refer to the introduction to this volume (Larios and Voix 2018).

17. Perhaps it never will and this could be precisely one of the characteristics of street-shrines, namely that they allow for multiple narratives to coexist without one necessarily dominating the other.

18. Śani Mahārāj or Saturn is considered the most malefic of the nine planetary deities (navagraha ). Śani's inauspicious influence is defined through a series of cosmological entities associated with the planet Saturn such as the black colour, the tamas quality (guna), the śüdra class (varna) and so on. The specialist dealing with the planet Saturn who is able to identify his heavenly positions and evaluate his influence on human destiny is the astrologer (jyotiși) and the ritual specialist, is often the same person (Cerulli and Guenzi 2016; Marchetto and Hoefer 2016). However, these ritual specialists (pujārīs), at least in north India, are members of the dakaut caste which is officially classified as Other Backward Class (OBC) by the Indian government. Despite their "lower" social status, according to Bellamy these ritual specialists "self-identify as professional astrologers and Brahmins whose special work involves serving as mediators between Śani and humanity" (2014:25). For additional information about the worship of Śani and Mārutī in Maharashtra see Brackett (2004:51-74).

19. I was not able to procure more details about lieutenant Kulkarni, and I was also not able to interview him directly, but I hope to do so in the near future.

20. It is not uncommon to worship Śani as an aniconic black stone or piece of base metal, such as iron. Often these shrines are portable. For some images of Śani in both his aniconic and iconic forms, see Bellamy (2014).

21. Bellamy notes that in Delhi too most Śani mürtis conform to the convention that they "should be open to the sky" (2014:25, FN 4). 
22. This is a 40-verse hymn dedicated to the God composed by the 16th-century poet-saint Tulsīdās.

23. For instance, I noticed that some children and a young man who were standing in line to take darśan of Mārutī and Śani observed as an elderly man applied a mark on his forehead (țīka ) from the ashes from incense offered at the base of the tree next to Śani. As they saw the man apply ash on their forehead the young man first followed the practice of the elderly man, and immediately the children copied the young man. After applying the ashes on the forehead the elderly man went and bowed to the deity of Śani, but putting his hands behind his back. The children and the young man performed the exact same gesture to show their respect. While applying ritual marks on the forehead is common practice, taking ashes from the burnt incense offered to the deity is something less common. Bowing is also a universal way of offering one's respect in Hindu practice. However, putting one's hands behind one's back as one bows to the deity is not common. It seems to me that the devout attitude of the elderly man inspired the young man and children to mimic this devotional practice. Similarly, other devotees seem to often inspire each other in their ritual practices.

24. Lutgendorf comments on the episode of the Hanumāyana called "The Defeat of Śani" that explains why "it is notable that many Maruti temples in Maharashtra contain a small icon of Shani who is worshiped with oil offerings on Saturday" (Lutgendorf 2007:233). In the episode, Saturn comes to bother Hanumān in his old age, but the god ultimately crushes him under five rocks until he begs for mercy. Lutgendorf summarizes the scene thus: "Now Shani screams for mercy: 'Save me, Son of the Wind! Save me, Messenger of Rama! I promise henceforth never to afflict anyone who remembers you!' Hanuman is pleased, especially by the invocation of his Lord, and removes the boulders. Shani descends, pressing his bruised limbs. He swears to keep his word, then asks Hanuman for some mustard oil to massage his aching body. Hanuman is already settling down for meditation: 'Sorry, fresh out. Better ask someone else"' (Lutgendorf 2007:175). Bellamy concludes that mustard oil is therefore: "a substance that is used to absorb, contain and transfer negative influences, and it is a substance offered to please (in this case, heal) the god" (Bellamy 2014:34). Other traditional Śani-pleasing offerings besides mustard oil include black sesame seeds, iron nails, and black cloth (Bellamy 2014:32). However, during my fieldwork I only observed the offering of black sesame seeds on one occasion.

25. I plan to conduct more research on these shrines in the near future to answer this and other questions.

26. Brackett also notes that the worship of Mārutī also tends to be of a very short duration. Describing the ritual procedure at the famous Śanipār Mārutī Mandir located in old Pune he notes: "The entire process of darśan took no more than a minute of two. In part, the speed was to facilitate movement of the usual long line of devotees present on Saturday" (Brackett 2004:65). He suggests that the simple and short duration of his worship "resonated with the felt needs of residents in the sprawling urban environment of Pune, a place where one's busy lifestyle often left little time for long, elaborate rituals" (Brackett 2004:65).

27. Bellamy has noted an increase of Śani worship and temples in Delhi whose main clientele comes from the middle-class. She notes that important characteristics of these new temples is that they "are influenced by an urban environment dominated by ownership of houses; their leadership is hired rather than hereditary; and their space and polity reflect democratic models of civic organizations" (Bellamy 2014:25). She also notes that in the urban setting of Delhi the hereditary role of the "Dakauts' as Śani's pujārīs-and with it, perhaps, certain connections between notions of religiosity and notions of caste-has become less relevant" (Bellamy 2014:36). 28. According to the Indian Express, Anil Kumbhare, Deputy Commissioner of Police (Zone II) said that: "Some call him Robinhood, for whenever he returns from Mumbai with the loot, he donates money to the unemployed and needy" (Sood 2011). 
29. Philip Lutgendorf has described a famous Hanumān shrine in Benares in his book Hanuman' Tale established by one Lallu Singh Pahalvan, a famous gūndā in the 1970s (Lutgendorf 2007:255). Other examples of patronage of thieves to gods and goddesses are found elsewhere in India, for instance the famous thief from Punjab, Jani Chor, who after being saved by the Goddess gifted her a golden canopy (Bhatti 2000:124-25). A film named Jeona Morh inspired in the robber's life was released in 1991. The Kanjars, a caste of professional thieves in rural Rajasthan are also known for their patronage to Joganiya Mata (literally, 'yogi mother'), who is also known as the "goddess of thieves" (chorõ kī devì). See, for instance, Piliavsky (2015).

30. This is perhaps best condensed in the slogan she presents in her article from the Śani Dhām's website that reads: "Śani śatru nahin mitr hai-Śani: friend, not foe" (Bellamy 2014:36).

31. The friend who introduced me to this temple shared with me that she used to visit the temple with her children when they were young as they all enjoyed going for darśan there and it was a convenient location close to their home. One day she heard the pet-name of the temple (Corãñā Ganpatī) from a friend and asked about the story behind it. Once she discovered that a famous burglar was behind the temple, she decided to stop visiting the temple, even if she confessed finding the "mūrti of the temple and the place itself very beautiful."

32. For instance, to worship in states of ritual impurity according to brahmanical standards or to offer one's salutations with one's shoes still on and even without getting off one's vehicle.

\section{ABSTRACTS}

This article presents the results from brief ethnographic research conducted in 2016 in the city of Pune, Maharashtra. Through two case studies of wayside shrines in Pune-the first, a tiny pavement shrine which is steadily growing in popularity, and the second, a small shrine turned into an extravagant temple in just a few years-I consider them as more than just spontaneous expressions of devotion. Taking into consideration the roles that urban conditions and social configurations have been playing in how social actors forge connections between localities and different communities, this paper will look at how these shrines can be spaces of creative subversion of the established socio-religious order and its structures of power. In in this contribution, I argue that the wayside shrine reveals the blurred boundaries between the rural and the urban, the sacred and the mundane, the institutionalized and the popular as well as the legal and the illegal.

\section{INDEX}

Keywords: wayside shrines, urban religion, Hinduism, Pune, institutionalization, third-space

\section{AUTHOR}

\section{BORAYIN LARIOS}

South Asia Institute, University of Heidelberg 